\title{
Managing knowledge in supply chains: a catalyst to triple bottom line sustainability
}

Article

Accepted Version

He, Q., Gallear, D., Ghobadian, A. and Ramanathan, R. (2019) Managing knowledge in supply chains: a catalyst to triple bottom line sustainability. Production Planning and Control, 30 (5-6). pp. 448-463. ISSN 0953-7287 doi:

https://doi.org/10.1080/09537287.2018.1501814 Available at https://centaur.reading.ac.uk/77834/

It is advisable to refer to the publisher's version if you intend to cite from the work. See Guidance on citing.

To link to this article DOI: http://dx.doi.org/10.1080/09537287.2018.1501814

Publisher: Taylor \& Francis

All outputs in CentAUR are protected by Intellectual Property Rights law, including copyright law. Copyright and IPR is retained by the creators or other copyright holders. Terms and conditions for use of this material are defined in the End User Agreement.

\section{www.reading.ac.uk/centaur}

\section{CentAUR}

Central Archive at the University of Reading 
Reading's research outputs online 


\title{
Managing Knowledge in Supply Chains: A Catalyst to Triple Bottom Line Sustainability
}

\author{
Qile He, David Gallear, Abby Ghobadian, Ramakrishnan Ramanathan
}

\begin{abstract}
Sustainable supply chain management (SSCM) has attracted the attention of researchers in recent years. Arguably the interest in SSCM is stimulated by the triple bottom line (TBL) which itself has received significant attention. In addition, knowledge management (KM) and its positive role in improving facets of supply chain development and performance have been topics of interest to academics. Despite all this positive development there is a paucity of theoretical and empirical studies identifying the broad capabilities that affect a firm's ability to simultaneously pursue economic, environmental and social success. In this paper we use the natural-resource-based view (NRBV) and the knowledge-based view (KBV) to develop a series of propositions linking KM capability to strategic and operational supply chain sustainability and competiveness. We further test the veracity of these propositions by ascertaining the perceptions of 275 practicing managers using a survey instrument. The paper offers a systematic analysis of KM's role in the development of sustainable supply chain (SSC) strategies and operations respectively. The findings confirm the credibility of a set of theoretical propositions derived from the extant literature, and also identify how different KM processes specifically facilitate strategic or operational development of SSCs. The paper provides researchers with a framework and understanding to guide future research on KM as a catalyst to the TBL in supply chains.
\end{abstract}

Keywords: knowledge management, sustainable supply chain management, operational improvement, natural-resource-based view, triple bottom line.

\section{Introduction}

The triple bottom line (TBL) - a conceptual framework put forward by Elkington (1998) - attributes organisational success to attaining balanced performance between business, environmental and social dimensions or alternatively profit, planet and people (3Ps). Since its introduction nearly two decades ago the TBL has found increasing favour among practicing managers and academics due to its perceived positive impact on competitiveness. The quote - profit is no more the purpose of business than breathing is the purpose of life - attributed to John Kay, a respected economist and FT columnist (Confino, 2014), captures the spirit of the TBL. Supply chain management is not exempt from this trend and the TBL is increasingly influencing the conceptual development of the next generation of sustainable supply chain management (SSCM) concepts and practices. However, it is not clear to what extent practices underlying these concepts find favour among the practicing managers. This paper sheds some light on the actual views of practitioners with respect to SSCM. 
The importance of spreading sustainable development along the supply chain and establishing sustainable supply chains (SSCs) has attracted the attention of an increasing number of researchers (e.g., Chaabane et al., 2011; Hollos et al., 2012; Pagell and Wu, 2009). Inspired by the TBL concept (Elkington, 1998), a growing number of researchers have explored the means to improve the sustainable performance of supply chains while maintaining the competitive advantages of firms (e.g. Carter and Rogers, 2008; Hollos et al., 2012; Isaksson et al., 2010).

Arguably one of the most important outcomes of the prior theoretical work is the establishment of a positive link between supply chain sustainability and firms' knowledge-based activities (e.g., Carter and Rogers, 2008; Irani et al., 2017). The extant literature suggests that when the lower hanging fruits in terms of simple in-house business solutions are exhausted, deeper knowledgebased collaborations between supply chain actors offer better opportunities to identify and exploit more radical solutions (Carter and Rogers, 2008; Cheng et al., 2008; Zhu et al., 2009). Despite the significant importance attached to knowledge management (KM), our understanding as to how KM can facilitate the development of competitive sustainable supply is nascent. Many definitions of KM exist. In this study we adopt the definition proposed by Pawlowsky (2003) as the working definition of KM because it supports the operationalization of the concept in organisational settings. According to Pawlowsky (2003), KM is concerned with the organisation's management of learning processes including identification, generation/creation, diffusion, integration, modification, and application of knowledge, at individual, group, organizational or inter-organisational levels.

In conducting our study we draw on two interrelated theoretical lenses, namely the naturalresource-based view (NRBV) and the knowledge-based view (KBV). Hart (1995) proposed the NRBV, postulating that competitive advantage in coming years would be rooted in capabilities that facilitate environmentally sustainable economic activity (Hart, 1995: 991). The NRBV draws on the resourcebased view (RBV) as well as the knowledge-based view (KBV) of the firm identifying three key strategic capabilities - pollution prevention, product stewardship, and sustainable development (Hart, 1995; Hart and Dowell, 2011). Sustainable development seeks to produce in a way that can be maintained into the future and it is not restricted to environmental concerns but also involves focusing on economic and social concerns (Hart, 2007). Knowledge (and its effective management) is a critical resource/capability underpinning pollution prevention, product stewardship and sustainable development strategic capabilities (Hart and Sharma, 2004). Hart and Dowell (2011) pointed out that most application of the NRBV has been focused on pollution control, with much less attention to empirical research on product stewardship or sustainable development. The current paper attempts to address this gap by developing theoretically driven propositions drawing on the NRBV, the KBV and $\mathrm{KM}$ and testing the extent that these propositions are supported by practicing managers.

In terms of the supply chain, Carter and Rogers (2008) suggest that cooperation on sustainability along the supply chain should be built upon a solid foundation of shared knowledge and understanding between supply chain partners. They insinuate that supply chains that integrate social and environmental resources and knowledge are more difficult to imitate, thus leading to greater relative economic sustainability. Case studies of sustainable practices further highlight the potential role of KM in facilitating change within firms (e.g., Mollenkopf et al., 2010; Stokes and Tohamy, 2009). Despite the significant progress there is a shortage of rigorous conceptual analysis identifying 
capabilities that underpin sustainability (Hart and Dowell, 2011). In this paper - synthesising the NRBV, the KBV and KM literature - we develop a conceptual model linking KM with SSCs. We then examine if theory and practice are aligned by ascertaining the views of practicing mangers for each of our theoretically driven propositions. This addresses another gap, namely the paucity of empirical research systematically examining the views of practitioners with regards to the sustainability of supply chains (e.g., Irani et al., 2017). Developing a systematic understanding of how effective KM might enhance the sustainability of supply chains and linking it to the perception of practicing managers is both timely and relevant.

Our theoretically driven propositions highlight the latent value of KM activities in developing SSCs and its potential positive impact on performance. Theory will remain theory unless it is put in to practice. The NRBV theory suggests that managerial attention and framing of environmental issues affect a firm's ability to profitably enact environmentally proactive strategies such as sustainable development (Hart, 1995). This notion is supported by empirical research. For example, King and Lenox (2002) showed that managers do not find profitable opportunities where they do not look for them, and thus the ability to profit from pollution prevention or sustainability depends critically on manager's expectation that such opportunities exist. This suggests that managerial cognition is critical to a firm's sustainability drive. Hence, theories will remain theories unless there is strong purchase among practicing managers. The captains of industry 'talk the talk' and appear to veer on the side of the TBL, as a recent criticism of businesses fixated with the shareholder value at the expense of purpose by Carolyn Fairbairn the CBI's Director General, among others, suggests (FT, 2017). But it is not clear how widely such views are accepted among the vast array of practicing managers. These arguments suggest that it is essential to systematically ascertain the views of practitioners. Given the lack of systematic empirical evidence, this paper therefore seeks to examine how effective KM facilitates SSC development by ascertaining the perceptions of practitioners, and by both developing a foundation and generating an impetus for more effective future research on the interplay between KM activities and supply chain sustainability efforts.

This paper adopts an exploratory perspective commensurate with the lack of extant empirical evidence in this area to date. To this end, the study first used the available literature, anchored in the NRBV and KBV, to develop a set of propositions linking KM and SSCM and an accompanying conceptual framework. Together, these formed the basis for the development of an exploratory survey of field practitioners, with the objective of ascertaining their perceptions on the general role of KM in facilitating supply chain sustainability, and on the relative importance of various KM processes to SSC development strategically or for operational improvement.

In this way, this empirical work helps to provide clarity to practicing managers on if, why and how (i.e. through which KM processes) KM can contribute to achieving TBL sustainability. Secondly, and equally importantly, it also seeks to ascertain if all of the KM process elements are equally important to SSC development, or if there are in fact differences in the locus ('strategic' level versus 'operational' level) of the different KM processes' contribution. In other words, which aspects of KM most need to be addressed through a 'strategic lens', and which KM aspects most need to be addressed through an 'operations lens' (i.e. by those who are more directly engaged with the frontline detailed design, coordination and management of the value-adding processes)? 
Establishing if such differences exist is important for practicing managers, because where they are found to exist, greater clarity can be provided to supply chain members on where within the firm hierarchy the responsibility for leading which of the different KM processes should primarily reside (i.e. at the strategic, or at the operational level). The findings will also therefore help to provide guidance to supply chain member firms on which specific types of KM process competencies and/or skills need to be developed amongst employees operating at the strategic level, and which need to be developed amongst employees working at the operational level. Likewise, the findings will therefore help to provide guidance to supply chain member firms on the types of knowledge management-related resource investment they may need to make in order to support SSC strategy development, and the types they may need to make in order to support the development of SSC operations.

The remainder of the paper comprises four sections. The next section presents our review of the literature and the development of the propositions and conceptual framework. The research sample and data collection methods are then discussed. Analysis of the empirical data and its implications are then presented, leading in the final section to our conclusions, managerial implications and suggested directions for further research in the field.

\section{Literature and propositions}

\subsection{Triple bottom line and sustainable supply chains}

A question increasingly attracting the attention of practitioners and academic is: how can the sustainability of supply chains be enhanced? (e.g. Hall and Matos, 2010; Markley and Davis, 2007; Zhu and Sarkis, 2004). To this end a growing number of researchers are exploring the elements, methods and mechanisms of supply chain sustainability from different environmental or social perspectives (e.g. Beske et al, 2008; Govindan et al., 2013; Seuring and Muller, 2008; Zhu et al., 2012).

The TBL (Elkington, 1998) combined with the NRBV (Hart, 1995) has encouraged scholars towards a broader framing of sustainability not only in terms of the means and the end destination but also its boundary delineation, beyond the single firm to encompassing supply chains (e.g. Carter and Rogers, 2008). Carter and Rogers (2008) suggested that at the intersection of social, environmental, and economic performance, organizations can engage in activities which not only positively affect the natural environment and the society, but also result in long-term economic benefits and sustained competitive advantage for the firm. Carter and Rogers $(2008$, p.368) therefore defined SSCM as the 'strategic, transparent integration and achievement of an organization's social, environmental, and economic goals in the systemic coordination of key inter-organizational business processes for improving the long-term economic performance of the individual firm and its supply chains'. Furthermore, Pagell and Wu (2009) highlighted that for a supply chain to be truly sustainable its activities should lead to no net harm to natural or social systems while maintaining its customer base and profitability. Accordingly, in this paper, SSC is referred to as the supply chain meeting economic, environmental and social requirements of the firm at the same time (Carter and Rogers, 2008). This definition takes account of the different supply chain management goals, and extends the traditional supply chain management concept to incorporate sustainability into the management process. 
SSCM extends the sustainable practices from the firm level to an inter-firm level through more of an integrated, boundary spanning process that is not just the effort of one firm (Carter and Rogers, 2008). The development of a SSC requires the cooperation throughout the supply chain process and may involve multiple domestic and international partners. Improving the sustainable performance of a supply chain therefore can become a very complex task especially when the various parties involved in the supply chain processes have inconsistent performance goals. It is reasonable to argue that knowledge and its effective sharing and management, therefore underpins SSCM (Cheng et al., 2008; Carter and Rogers, 2008; Zhu et al., 2009).

\subsection{Knowledge management in supply chains}

A body of literature posits that "knowledge" is a critical source of competitive advantage. Grant's (1996) pioneering paper popularised the knowledge-based view of the firm (KBV) postulating that knowledge is an important corporate resource, thus emphasizing the firm's role in creating, storing and applying knowledge. The KBV considers knowledge as an essential source of competitive advantage, positing that firms' competitive advantages derive from their preferential access to idiosyncratic resources, especially tacit knowledge-based resources, which could be located internally or possessed externally by other organizations (Conner and Prahalad, 1996).

The KBV also advocates the imperfect congruence of the firms' products and internal knowledge domain and therefore suggest that a firm's ability to access, transfer and apply the specialized knowledge will determine the efficiency of its efforts to integrate specialized knowledge into the value creation process (Grant and Baden-Fuller, 1995). Similarly, the absorptive capacity view (Cohen and Levinthal, 1990) captures the ability of firms to identify, assimilate, and exploit knowledge from the environment, thus advocating the importance and the value of external knowledge sources. The processes of managing knowledge can apply at many different levels, between individuals or amongst different organizations.

Given the centrality of knowledge it is little surprise that there is a growing body of KM focused literature examining the processes of capturing, storing, manipulating, and applying internal and external knowledge by the firm as well as its impact on the organizational performance (EasterbySmith and Lyles, 2003; Meier, 2011). Despite all of these efforts there appears to be no final consensus regarding KM's definition or classification (e.g., Alavi and Leidner, 2001; Davenport et al., 1998; Easterby-Smith and Prieto, 2008; Pawlowsky, 2003). Among the various contributions however, Pawlowsky's (2003) classification is arguably more expansive, and therefore offers greater scope for identifying and differentiating the potential effect of KM in the supply chain processes. Taking our lead from Pawlowsky (2003), our focus in the current study is on KM processes and their influences on SSCM.

According to Pawlowsky (2003), KM consists of six interrelated processes. First is knowledge identification, which encompasses the identification of new techniques, technologies, information, and knowledge from internal and external sources, by making internal knowledge visible, or by accessing external sources of new knowledge through boundary-spanning activities such as establishment of contracts with customers. Second is knowledge generation/creation - the 
construction of new knowledge, the development of new ideas and innovation within organizations. Third is knowledge diffusion - the transmission of knowledge through exchange, distribution, and sharing of knowledge within the firm and/or with external organizations. Fourth is knowledge integration - the assimilation of new knowledge into existing knowledge/systems of the firm at a collective level, an individual level, or both. Fifth is knowledge modification, which encompasses converting, altering or reforming the existing knowledge base of the firm. Sixth is knowledge application - putting knowledge (often new knowledge resulting from one or more of the previous processes) into action by applying it to the routines of the firm. These processes co-exist in firms' daily operations, and may sometimes facilitate each other on a sequential or non-sequential basis.

The arguments presented above point to the importance of "knowledge" as a source of competitive advantage, $\mathrm{KM}$ as a process focused on effective shepherding of and utilization of knowledge internal or external to the organisation, and the context specificity of $\mathrm{KM}$. In this research we are specifically concerned with KM processes in the context of firms' supply chains which go beyond firm boundaries. In the following sections we examine and propose how KM can facilitate firms' SSCM in relation to the meeting of TBL goals.

\subsection{Knowledge management enabled supply chain environmental performance}

The NRBV postulates that competitive advantage is rooted in capabilities that facilitate environmentally sustainable economic activity (Hart, 1995). Hart (1995) identified three broad strategies underpinning the NRBV - pollution prevention, stewardship, and sustainable development - pointing out that each has different driving forces, builds upon different key resources, and has a different source of competitive advantage. Hence, to implement any of the three strategies underpinning the NRBV, firms need to identify and develop new capabilities involving the leveraging of internal and external knowledge resources (Hart, 1995).

The development of new capabilities and competencies, in turn, is dependent on the firm's innovative capabilities along with their skills in the implementation of new projects (Christmann, 2000). Arguably, innovative and sustainability capabilities are complementary (Hart and Dowell, 2011). The extant literature distinguishes between resources and capabilities. Broadly stated, a resource is something that a firm possesses, which can include physical and financial assets as well as employees' skills and organizational (social) processes. A capability, in contrast, is something that a firm is able to perform, which stems from resources and routines upon which the firm can draw (Judge and Douglas, 1998, Karim and Mitchell, 2000; Winter, 2000). Innovative capability is critically dependent on knowledge and its management (du Plessis, 2007; Grant, 1996). Moreover, transorganisational capabilities also, are critically dependent on knowledge and its management (Grant, 1996; Lorenzoni and Lipparini, 1999). These arguments suggest that to foster SSCM, firms must develop sustainability related capabilities which, in turn, requires fostering of innovative capabilities, both of which require knowledge development and absorption.

This logic, grounded in the NRBV, applies to the focal firm's value chain and can be extended to a chain or a network of supply chain partners. The NRBV not only advocates firm's integration of environmental concerns internally but also implies broader collaboration with external organizations (Hart, 1995). Previous research has generally agreed that sustainable development of business 
organizations does not stop at the firm level, but instead that changes across the supply chain are needed to enable the true sustainability of any focal firm (Pagell and $\mathrm{Wu}, 2009$ ). Individual firms will not be truly sustainable until their suppliers and customers also embrace and follow sustainable processes.

To build more environmentally-sustainable supply chains, much wider collaboration and cooperation between supply chain partners is needed (Zhu and Sarkis, 2004). Central to such collaboration is the sharing of knowledge and best practices between supply chain partners in order to enhance their green capabilities (Cheng et al., 2008; Luthra et al., 2015) recognising that relevant innovations in processes and products do not always originate from within the organization itself (Boerner et al., 2003; Isaksson et al., 2010). In its strategy to create a more sustainable supply chain for example, Ford Motor Company emphasized the importance of collaboration and sharing of processes and best practices with its supply chain partners. Workshops and joint training programmes were launched to facilitate coordination amongst supply chain partners and improvements in the environmental performance of its supply chain (Ford.com, 2010). One of the main driving forces behind such strategies is the enlargement of green supply chain operations through outward-looking collaborative KM processes.

The arguments we have presented above, drawing on the NRBV and the KBV theoretical lenses, suggest that sustainability requires firms to develop new capabilities and that innovation and sustainability capabilities are complementary. Both capabilities are knowledge dependent. We further pointed out that the sustainability concept has broadened beyond a single firm boundary to encompass the firm's supply chain. Effective inter-organisational collaboration is also dependent on effective management and sharing of knowledge as was indicated above. The combination of these arguments suggest that a firm with greater competencies to acquire, absorb and apply external knowledge will be better equipped to develop capabilities necessary for fostering SSCM. The following two propositions capture these arguments:

Proposition 1a: Effective knowledge management by a focal firm will facilitate its capability to develop supply chain operations which benefit the environmental performance goals of the firm and its supply chain.

Proposition 1b: Effective knowledge management by a focal firm will facilitate its capability to develop supply chain strategies which benefit the environmental performance goals of the firm and its supply chain.

\subsection{Knowledge management enabled supply chain social performance}

One strand of the TBL focuses on the social outcomes of businesses (Elkington, 1998). Similarly, the NRBV points out that sustainable development by its very definition, is not solely fixated with environmental concerns, but also involves focusing on economic and social concerns (Hart, 1995). The social concern is predicated on engagement with a wide range of stakeholders and encompassing stakeholder value as a means to gain competitive advantage (Markley and Davis, 2007). From a supply chain perspective, social responsibility is not only synonymous with business ethics, but also encompasses dimensions including philanthropy, community, workplace diversity, 
safety, human rights, cause-related marketing, minority support, and socially responsible employment and manufacturing processes (Markley and Davis, 2007).

Aragon-Correra and Sharma (2003) showed that sustainable strategies are dependent upon specific and identifiable processes and are socially complex, hence they require path dependent and embedded capabilities. The fostering of such capabilities involves developing abilities to deal with areas of knowledge that are uncertain, constantly evolving, and dynamically complex (AragonCorrera and Sharma 2003; Hart and Sharma, 2004). Turning to the supply chain, previous research suggests that cooperation and integration between supply chain actors advances the prospect of the emergence of a socially responsible vision for the supply chain (Carter and Jennings, 2002; Gallear, et. al., 2012; He et al. 2006; Spence and Bourlakis, 2009). The social performance of supply chains can benefit from enhanced alignment of supply chain partners' business strategies and social/ethical standards (Gallear, et al., 2012). To this end, firms need to establish cooperative mechanisms between supply chain partners (Gallear, 2012; He et al., 2006; Linton et al., 2007). Inevitably, this requires not only the exchange of information between supply chain actors but also, as proposed by Boerner et al. (2003), innovative changes in the conventional business approaches such that effective management of knowledge resources can augment alignment. Porter and Kramer (2002) concluded that it is not only knowledge creation and acquisition that is needed to bring benefit to the philanthropic performance of corporations, but also knowledge dissemination. Moreover, any mismatch between a firm's 'words' and its 'deeds' can fatally undermine its credibility, and in this sense, a firm must be consistent in addressing its responsibilities in different parts of the business and among its business partners including remote suppliers or purchasers. Shared vision, therefore, needs to be established not only internally, but also along a firm's supply chain. The argument presented above leads us to conclude that the effective management of knowledge from internal and external sources along the supply chain is critical to assisting the complex change process required for developing path dependent capabilities critical to the design and implementation of socially responsible actions and strategies. Therefore, based on tenets of the NRBV and the extant literature presented, we develop our second set of propositions:

Proposition 2a: Effective knowledge management by a focal firm will facilitate its capability to develop supply chain operations which benefit the social performance goals of the firm and its supply chain.

Proposition 2b: Effective knowledge management by a focal firm will facilitate its capability to develop supply chain strategies which benefit the social performance goals of the firm and its supply chain.

\subsection{Knowledge management enabled supply chain business performance}

The KBV posits that knowledge resides in specialised forms among individual organisational members (and in the case of supply chains, individual firm members), and hence the essence of organisational capability is the integration of individual (and accordingly in the case of supply chains, individual firm members) specialist knowledge (Grant, 1996). For a capability to contribute to competiveness it has to add value, be rare, be inimitable and be embedded in the organisation (Barney, 2001). Grant (1996) argued that the capability to create and manage tacit knowledge was critical to a firm's long-term competiveness not least because tacit (specialist) knowledge inherently 
retains the characteristics associated with a capability critical to fostering long-term competiveness. Hult et al. (2004) in their seminal paper extended the KBV to supply chains, demonstrating that unique abilities to create and exploit wisdom help to improve supply chain performance (Hult et al., 2004). Since then, other studies have demonstrated a close link between KM and supply chain performance (Blome et al, 2014; Hult et al., 2007). Such studies suggest that in the case of supply chains, KM bolsters the ability of the supply chain partner firms to create and exploit wisdom and as a result improve performance (Hult et al., 2007). For example, more sustainable supply chains can be managed by closer sharing of knowledge via appropriate systems (Cheng, 2008). Innovations in products and processes can be shared across the supply chain via appropriate channels to improve sustainability of the entire supply chain. Thus, KM enables firms to gain competitive advantage and improve the supply chain's operational performance as a whole (e.g. Blome et al., 2014; Handfield et al., 1999; He et al., 2013; Hult et al., 2006; Modi and Mabert, 2007; Wadhwa and Saxena, 2007). Furthermore, effective KM along the supply chain facilitates innovation in products, services and processes, and improvements in supply chain relationships and supply chain flexibility (e.g. Bouncken et al., 2016; Johnsen et al., 2006; Malhotra et al., 2005; Wadhwa and Saxena, 2007; Wood et al., 2016).

Substantial evidence in the literature indicates that various KM mechanisms, such as collaborative learning (Bessant et al., 2003), knowledge acquisition (Hult et al., 2004), knowledge sharing (Dyer and Nobeoka, 2000; Lawson et al., 2009) and knowledge transfer (Kotabe et al., 2003), will enable firms' development of supply chain operational advantages, which eventually lead to superior supply chain business performances. Taking account of this prior literature, the following propositions are therefore advanced:

Proposition 3a: Effective knowledge management by a focal firm will facilitate its capability to develop supply chain operations which benefit the business performance goals of the firm and its supply chain.

Proposition 3b: Effective knowledge management by a focal firm will facilitate its capability to develop supply chain strategies which benefit the business performance goals of the firm and its supply chain.

\subsection{Supply chain sustainability and the competitive advantage of firms}

The NRBV extends the RBV theory by positing that firms' competitive advantage is embedded in the capabilities that enable environmentally sustainable economic activity (Hart, 1995). This suggests that by integrating the natural environment into the strategic planning process firms are better positioned to develop a valuable, potentially rare, and not easily imitated organizational capability (Judge and Douglas, 1998). As previously mentioned, the NRBV identifies three distinct strategies open to firms: pollution prevention; product stewardship; and sustainable development (Hart, 1995). Hart (1995) further pointed out that each of these three approaches has different antecedents, requires different capabilities and offers a different source of competitive advantage (Hart, 1995). As was mentioned earlier, there is a paucity of empirical research examining the antecedents and capabilities supporting sustainable development strategies (Hart and Dowell, 2011) - a gap we address in this paper. 
Other scholars argue that the growing constraints imposed by the consideration of the natural environment is likely to move the basis for gaining competitive advantage, now and in the future, to possessing a set of emerging capabilities such as waste minimization, green product design, technology cooperation and greening the suppliers (Flint and Golicic, 2009; Gopal et al., 2016; Lee et al., 2015). A firm's competitive advantage is sustainable not solely because of its possession of hard to imitate economic capabilities, but also because of its capabilities to effectively manage the relationship between economic, environmental and social factors (Hart, 1995; Hart and Dowell, 2011). Such capabilities enable the firm to deal with uncertainties at the interface between business operations, ecological issues, social welfare and ethical standards, and help to develop sustainable competitive advantages.

Modern supply chains are multi-tiered networks that involve various types of suppliers across various demographic, socio-political, and geographic spread (He et al., 2013). To have equilibrium between the focal firm and its supply chain, there needs to be a degree of uniformity in some of their key corporate policies and behaviour that binds them together (Gilmore, 2015). In a strategic supply chain the focal firm increasingly assumes higher-order responsibilities, similar to the ones traditionally assigned to the state, allowing it to act as a catalyst for proto-institutionalisation of sustainability (Gallear et al, 2012; He et al., 2013; Palazzo and Scherer, 2008). If the NRBV holds true for a single firm there is no obvious reason to assume that it does not hold true in the case of supply chains. The aim of SSCM is to enhance the overall supply chain sustainability (Carter and Rogers, 2008). Extending the logic of NRBV to the supply chain suggests that implementation of SSCM is likely to positively impact performance, and hence improve the competitive advantage of the focal firm and its supply chain network. This argument led us to develop our final proposition:

Proposition 4: The development of sustainable supply chain management by a focal firm will enhance its competitive advantage.

The preceding propositions are illustrated in the conceptual framework shown in Figure 1 . The framework emphasizes that effective KM along the supply chain will facilitate the development of supply chain management strategies and operations which enable firms to achieve economic, environmental, and social goals simultaneously, and in turn, foster competitive advantage.

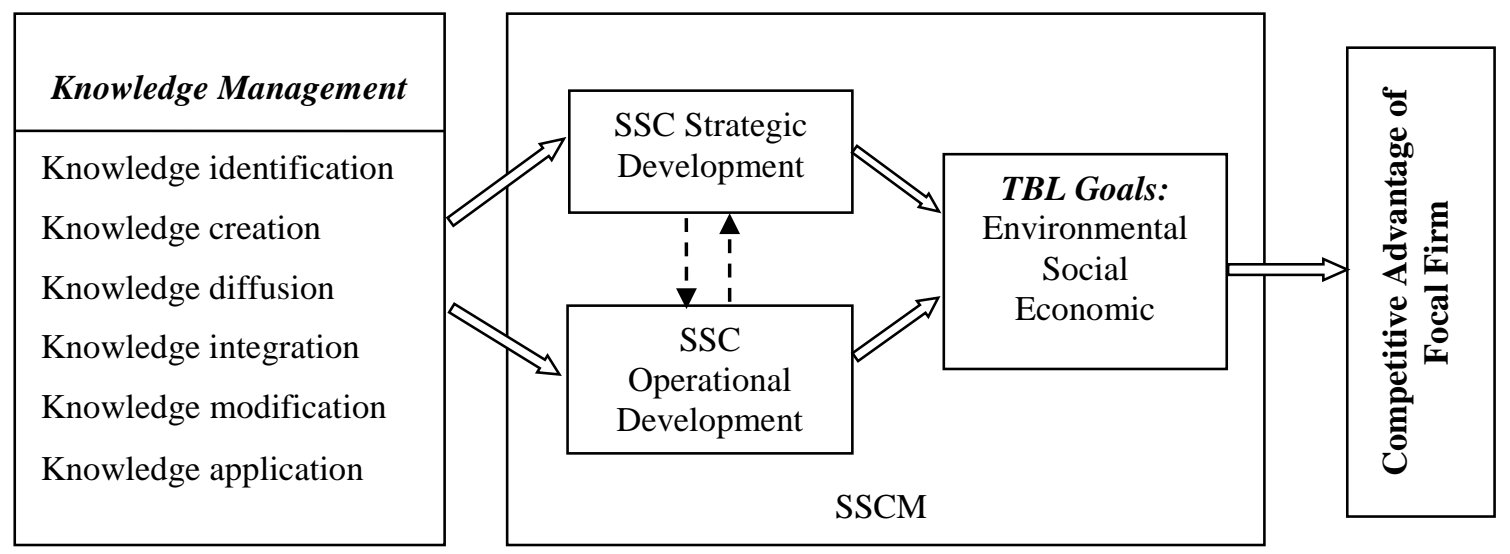

Figure 1. Conceptual framework of the role of KM in facilitating sustainable supply chains 


\section{Research methods}

Guided by our seven propositions, we undertook a survey with field practitioners, conducted via a self-administered questionnaire. The survey had two purposes: a) to examine and verify the potential role of KM in developing SSCs and how various KM processes would benefit SSC strategies and operations; b) to identify potential gaps in understanding between the literature and practitioners over the role of KM in developing SSCs, so that salient areas for future research could be identified.

Due to the exploratory nature of this study, we were interested in extracting how respondents perceive the potential role of KM in the development of SSC. To this end, we followed the typology of KM put forward by Pawlowsky et al. (2003, p.776) which indicates that a firm's KM-related activities include identification, generation/creation, diffusion, integration, modification, and application of knowledge, at individual, group, organizational and/or inter-organisational levels. We ensured that we stressed at the beginning of the questionnaire that KM processes internally and upstream or downstream in the supply chain was the main focus of the survey. Thus, respondents were asked to complete the questionnaire in the context of their firm's KM processes along the supply chain.

The survey instrument was developed based on previous literature - starting with questions to ascertain the general perceptions of respondents towards KM and the development of SSCs, then moving on to establish how respondents perceive the potential role of KM in the development of SSCs strategically and operationally. The questionnaire adopted a 7 point Likert-type scale, asking respondents to rate the importance of various KM processes (c.f. Pawlowsky et al., 2003) to firms' development of supply chain strategies and operations intended to meet economic, environmental and social goals simultaneously. The survey items, with related literature references, are shown in the appendix. The questionnaire was pilot tested with a panel of 36 field experts who had recent peer-reviewed articles published in key journals in the area of SSCM, to verify the consistency and clarity of the questionnaire items, and to help improve the precise wording. The questionnaire used in the pilot study included open-ended questions soliciting respondents' explanation of why KM does/does not benefit firms' SSC development efforts either strategically or operationally, and if they believe it does benefit SSC strategically or operationally, then how. Inclusion of the analysis of the open-ended questions not only enhances relevance of the study but it also affords opportunity for triangulation. The presentation of the results reported in section 4 therefore was constructed after also undertaking a comparison of the pilot results with the practising managers' responses (for example to identify any potential misalignment of views).

A target sample of practitioners was established based on purposive sampling through the Environment and Sustainability Forum of the Chartered Institute of Logistics and Transport (CILT) and the Cranfield University Alumni network. CILT's Environment and Sustainability Forum, with around 2,500 registered members throughout the world, is one of the largest forums focused on sustainability and the environment. Members of the forum are mainly practitioners with relevant experience in the area of logistics and supply chain management. Cranfield University is also well known for its professional education, and particularly its supply chain management courses. Alumni 
of Cranfield University are known to be active practitioners in various industry sectors around the world. We identified practitioners from relevant industrial sectors through the alumni network which offered a database of over 2,700 appropriate alumnus contacts. Given the exploratory nature of this study, both of these databases offered relevant and reliable sources for the sampling frame.

The survey instrument was delivered to the target respondents as an online questionnaire accessed via an email which contained a link. The instrument was sent out twice. This resulted in a total of 313 responses, of which 275 completed questionnaires were received from respondents who, through a filtering check, had suitable job roles or relevant experience. One hundred and seventeen (117) responses came from the CILT, and 158 from the Cranfield University alumni network. To ensure there were no significant differences between the CILT and Cranfield respondents, we followed an independent sample t-test procedure on the main survey constructs and demographic items to compare the CILT and Cranfield responses, and also to compare late and early responses. No significant differences were detected, and thus we were able to conclude that non-response bias did not appear to be an issue in this study (Musarra et al., 2016).

The respondents represented a wide range of industry sectors, including manufacturing, logistics, construction and retail/wholesale. A variety of firm sizes were also represented by the sample $-11.6 \%$ of the firms were micro firms, $21.1 \%$ of firms were small and medium-sized, and large firms accounted for $67.3 \%$ of the sample (see Table 1 ). Given that the TBL in the supply chain and KM are relatively new topics, it is not surprising to see that the larger proportion of respondents were from larger firms which tend to have better access to current information and knowledge. The majority of respondents were top managers or senior managers with relevant experience. Moreover, the majority of the respondents had been in their current position for more than 3 years.

Table 1. Demographics of the study respondents

\begin{tabular}{lrr}
\hline \multicolumn{1}{c}{ Industry } & Frequency & Percent \\
\hline Manufacturing & 41 & 14.9 \\
Logistics and Transport & 41 & 14.9 \\
Consultation and Business Services & 22 & 8.0 \\
Retail & 15 & 5.5 \\
ICT & 15 & 5.5 \\
Automotive & 14 & 5.1 \\
Construction and Real Estate & 13 & 4.7 \\
Telecoms & 12 & 4.4 \\
Oil and Gas & 10 & 3.6 \\
Electronics & 10 & 3.6 \\
Energy and Utilities & 10 & 3.6 \\
Healthcare & 9 & 3.3 \\
Food & 9 & 3.3 \\
Engineering & 7 & 2.5 \\
Defence & 6 & 2.2 \\
Chemicals & 6 & 1.8 \\
Technology & 275 \\
Pharmaceuticals & 5 & 1.5 \\
Others & 5 & 1.5 \\
\hline Total & 4 & 10.2 \\
\hline
\end{tabular}




\begin{tabular}{lrrr}
\multicolumn{2}{c}{ Number of Employees } & \\
\hline Less than 10 & 32 & 11.6 \\
$10-49$ & 22 & 8.0 \\
$50-249$ & 36 & 13.1 \\
250 or more & 185 & 67.3 \\
\hline Total & 275 & 100.0 \\
\hline & Position of Respondent & & \\
& & 41.8 \\
\hline Top managers/executives & 115 & 38.2 \\
Senior managers/Manager with relevant experience & 105 & 20.0 \\
Other middle level managers & 55 & 100.0 \\
\hline Total & 275 & \\
& Year in the Current Position & & 38.2 \\
\hline 1-2 years & 105 & 31.6 \\
3-5 years & 87 & 15.6 \\
6-10 years & 43 & 14.5 \\
\hline Total years & 40 & 100 \\
\hline
\end{tabular}

\section{Results and findings}

To examine the data collected, first mean scores of the responses to the structured questions within the survey instrument were examined using descriptive statistics. Second, Pearson correlations between survey responses were conducted to examine the relationship between different aspects of the practitioner perceptions. Third, paired-sample $t$ tests were carried out to examine whether there were significant differences between the perceptions of respondents in relation to different roles of KM processes (Bryman and Cramer, 2001). The findings from these analyses were then used to rank how strongly respondents perceive the importance of different aspects of KM.

\subsection{General role of KM}

The survey results provided strong support for the research propositions developed in this study. Regarding the general role of $\mathrm{KM}$, there is general consensus on the positive role that $\mathrm{KM}$ can play in the development of SSCS and the feasibility of SSCM in enhancing the competitive advantage of firms. This is indicated by the relatively high mean scores (greater than 5) for GKM1 through GKM6 and the significant correlations between different items (see table 2).

Table 2-General role of KM in facilitating SSC

\begin{tabular}{|c|c|c|c|c|c|c|c|c|c|}
\hline Items & Mean & $\begin{array}{l}\text { Std. } \\
\text { Dev. }\end{array}$ & $\begin{array}{l}\text { Std. } \\
\text { Error } \\
\text { Mean }\end{array}$ & GKM1 & GKM2 & GKM3 & GKM4 & GKM5 & GKM6 \\
\hline $\begin{array}{l}\text { GKM1. Firms will realise the economic } \\
\text { gain from adopting more proactive } \\
\text { social and environmental strategies. }\end{array}$ & 5.029 & 1.482 & 0.089 & 1 & & & & & \\
\hline $\begin{array}{l}\text { GKM2. Adopting supply chain strategies } \\
\text { that simultaneously emphasise } \\
\text { economic, environmental and social }\end{array}$ & 5.244 & 1.486 & 0.090 & $.779 * *$ & 1 & & & & \\
\hline
\end{tabular}


the competitive advantages of firms.

GMK3. To meet economic, environmental and social performance goals simultaneously,

\subsection{1}

**. Correlation is significant at the 0.01 level (2-tailed).

To examine whether there are differences in perceptions regarding the different aspects of the role of KM, a paired-sample $t$ test was conducted. As shown in Table 3, significant differences were found between the different aspects. We therefore ranked the items according to the direction of the mean differences and the significant mean differences (see Table 4). Through this process, the item with the greatest number of significant mean differences with other items are either ranked highest or lowest, depending on the sign of the mean differences. For example, GKM1 has the smallest mean score and has the largest number of significant mean differences in relation to other items. Hence, GKM1 is ranked the lowest compared to the other items, indicating that respondents least agree with this aspect of the role of KM. On the other hand, GKM3 has the highest mean score and has received a larger number of significant mean differences compared with other items. Hence, GKM3 is ranked highest indicating that the respondents are most supportive of this aspect of the role of KM. Examination of the rankings derived therefore indicates how respondents perceive each aspect of the role that KM can play in developing SSC.

Table 3. Paired perception mean differences on the general roles of KM

\begin{tabular}{|c|c|c|c|c|c|c|c|c|}
\hline \multirow[b]{2}{*}{ Pairs } & \multirow[b]{2}{*}{ Mean } & \multirow{2}{*}{$\begin{array}{c}\text { Std. } \\
\text { Deviation }\end{array}$} & \multirow{2}{*}{$\begin{array}{l}\text { Std. Error } \\
\text { Mean }\end{array}$} & \multicolumn{2}{|c|}{$\begin{array}{l}\text { 95\% Confidence Interval of } \\
\text { the Difference }\end{array}$} & \multirow[b]{2}{*}{$\mathrm{t}$} & \multirow[b]{2}{*}{$\mathrm{df}$} & \multirow{2}{*}{$\begin{array}{l}\text { Sig. }(2- \\
\text { tailed) }\end{array}$} \\
\hline & & & & Lower & Upper & & & \\
\hline GKM1 - GKM2 & $-0.215^{* * *}$ & 0.986 & 0.059 & -0.332 & -0.098 & -3.609 & 274 & .000 \\
\hline GKM1 - GKM3 & $-0.684 * * *$ & 1.382 & 0.083 & -0.848 & -0.520 & -8.202 & 274 & .000 \\
\hline GKM1 - GKM4 & $-0.618 * * *$ & 1.438 & 0.087 & -0.789 & -0.447 & -7.127 & 274 & .000 \\
\hline GKM1 - GKM5 & $-0.542 * * *$ & 1.443 & 0.087 & -0.713 & -0.371 & -6.228 & 274 & .000 \\
\hline GKM1 - GKM6 & $-0.473 * * *$ & 1.456 & 0.088 & -0.646 & -0.300 & -5.386 & 274 & .000 \\
\hline GKM2 - GKM3 & $-0.469 * * *$ & 1.279 & 0.077 & -0.621 & -0.317 & -6.080 & 274 & .000 \\
\hline GKM2 - GKM4 & $-0.404 * * *$ & 1.414 & 0.085 & -0.572 & -0.236 & -4.732 & 274 & .000 \\
\hline GKM2 - GKM5 & $-0.327 * * *$ & 1.384 & 0.083 & -0.492 & -0.163 & -3.922 & 274 & .000 \\
\hline GKM2 - GKM6 & $-0.258 * * *$ & 1.373 & 0.083 & -0.421 & -0.095 & -3.118 & 274 & .002 \\
\hline GKM3 - GKM4 & 0.065 & 1.188 & 0.072 & -0.076 & 0.207 & .914 & 274 & .362 \\
\hline GKM3 - GKM5 & $0.142 * * *$ & 1.090 & 0.066 & 0.012 & 0.271 & 2.158 & 274 & .032 \\
\hline GKM3 - GKM6 & $0.211 * * *$ & 1.159 & 0.070 & 0.073 & 0.348 & 3.019 & 274 & .003 \\
\hline GKM4 - GKM5 & 0.076 & 0.758 & 0.046 & -0.014 & 0.166 & 1.671 & 274 & .096 \\
\hline
\end{tabular}




\begin{tabular}{lllllllll} 
GKM4 - GKM6 & $0.145^{* * *}$ & 0.928 & 0.056 & 0.035 & 0.256 & 2.598 & 274 & .010 \\
GKM5 - GKM6 & 0.069 & 0.796 & 0.048 & -0.025 & 0.164 & 1.439 & 274 & .151 \\
\hline \multicolumn{10}{l}{ ***. Significant mean differences at $\mathrm{p}<0.05$} \\
\hline
\end{tabular}

Table 4. Ranking of perceptions of the general roles of KM in SSC

\begin{tabular}{cl}
\hline Rank & \multicolumn{1}{c}{ Perceptions of respondents } \\
\hline 1 & $\begin{array}{l}\text { GKM3 To meet economic, environmental and social performance goals simultaneously, firms need } \\
\text { innovation/transformation of their existing practices. }\end{array}$ \\
\hline 2 & $\begin{array}{l}\text { GKM4 Effective knowledge management is essential for a firm's development of sustainable supply } \\
\text { chain strategies. }\end{array}$ \\
\hline 3 & $\begin{array}{l}\text { GKM5 Effective knowledge management by a firm is critical for the innovation needed for more } \\
\text { sustainable supply chain operations. }\end{array}$ \\
\hline 5 & $\begin{array}{l}\text { GKM6 Firms with effective knowledge management are more able to develop sustainable supply } \\
\text { chain management. }\end{array}$ \\
\hline 6 & $\begin{array}{l}\text { GKM2 Adopting supply chain strategies that simultaneously emphasise economic, environmental } \\
\text { and social performance goals will contribute to the competitive advantages of firms. }\end{array}$ \\
\hline $\begin{array}{l}\text { GKM1 Firms will realise the economic gain from adopting more proactive social and environmental } \\
\text { strategies. }\end{array}$ \\
\hline $\begin{array}{l}\text { Note: Following mean differences, GKM1 - GKM2, GKM1 - GKM3, GKM1 - GKM5, GKM1 - GKM6, GKM2 - } \\
\text { significant. Ranking is based on signs of mean differences. }\end{array}$ \\
\hline
\end{tabular}

A number of salient findings derive from the analyses. First, practitioners are generally in agreement that business practice innovation is necessary for improving the sustainability performance of firms. Second, they also believe in the positive role of effective KM in developing SSC strategies and in facilitating innovations needed for developing SSC operations. Third, practitioners are also more guarded in the belief that firms with effective KM are better positioned to develop SSCM. There is a degree of symmetry between practitioners' response and field experts' response to the open ended question. The field experts, as a part of the pilot study, indicated that effective KM will potentially foster the development of innovation supporting growth of SSC strategy and operations, but the potential contribution may not always be direct, hence, it may not immediately generate direct operational and business returns. Instead, in reality, intentions outweigh actual practices in improving SSC performance. These latter observations, although emphasising the positive role of KM, also indicate that KM's impact may be indirect and hence difficult to draw direct attribution. In turn, this indicates a need for more longitudinal studies examining how KM affects sustainable development and competitiveness in the long-term. Fourth, practitioners in general are supportive, but relatively less convinced, about the possibility of balancing the supply chain economic goals with social and environmental targets simultaneously. We also found that they were somewhat sceptical that the pursuit of TBL goals can simultaneously improve firms' competitive advantage. This may also reflect the fact that corporate sustainability is still a significant challenge facing modern firms. These are significant findings in view of the importance of cognition in the sustainability drive discussed earlier.

\subsection{The role of specific KM processes in facilitating SSC strategy}

We next examined the role of specific KM processes in facilitating SSC strategy. As shown in Table 5, the high ratings for the KM processes, in addition to the significant correlations between the 
different KM processes, indicate that the practitioners in the sample are generally positive about the potential of the various KM processes for developing SSC at the strategic level.

Table 5. Role of specific KM processes in facilitating SSC strategy

\begin{tabular}{|c|c|c|c|c|c|c|c|c|c|}
\hline Pairs & Mean & $\begin{array}{l}\text { Std. } \\
\text { Dev. }\end{array}$ & $\begin{array}{l}\text { Std. Error } \\
\text { Mean }\end{array}$ & KMS1 & KMS2 & KMS3 & KMS4 & KMS5 & KMS6 \\
\hline $\begin{array}{l}\text { KMS1. Knowledge Identification - } \\
\text { SSC Strategy }\end{array}$ & 5.491 & 1.300 & 0.078 & 1 & & & & & \\
\hline $\begin{array}{l}\text { KMS2. Knowledge Creation - SSC } \\
\text { Strategy }\end{array}$ & 5.422 & 1.286 & 0.078 & $.819^{* *}$ & 1 & & & & \\
\hline $\begin{array}{l}\text { KMS3. Knowledge Diffusion - SSC } \\
\text { Strategy }\end{array}$ & 5.524 & 1.297 & 0.078 & $.798^{* *}$ & $.756^{* *}$ & 1 & & & \\
\hline $\begin{array}{l}\text { KMS4. Knowledge Integration - } \\
\text { SSC Strategy }\end{array}$ & 5.429 & 1.278 & 0.077 & $.780^{* *}$ & $.760^{* *}$ & $.857^{* *}$ & 1 & & \\
\hline $\begin{array}{l}\text { KMS5. Knowledge Modification - } \\
\text { SSC Strategy }\end{array}$ & 5.309 & 1.389 & 0.084 & $.771^{* *}$ & $.728^{* *}$ & $.765^{* *}$ & $.747^{* *}$ & 1 & \\
\hline $\begin{array}{l}\text { KMS6. Knowledge Application - } \\
\text { SSC Strategy }\end{array}$ & 5.338 & 1.350 & 0.081 & $.706^{* *}$ & $.742^{* *}$ & $.741^{* *}$ & $.741^{* *}$ & $.839^{* *}$ & 1 \\
\hline
\end{tabular}

To examine for differences in perceptions in relation to the different KM processes, a pairedsample $t$ test was conducted. As shown in Table 6, significant mean differences were found between the different KM processes, indicating that practitioners do not perceive the different KM processes as being equally important to SSC strategy development. As described above, we ranked the importance of each KM process, according to the direction of the mean differences and the significant mean differences (see Table 7).

Table 6. Paired perception mean differences in the role of specific KM processes in facilitating SSC strategy

\begin{tabular}{|c|c|c|c|c|c|c|c|c|}
\hline \multirow[b]{2}{*}{ Pairs } & \multirow[b]{2}{*}{ Mean } & \multirow{2}{*}{$\begin{array}{c}\text { Std. } \\
\text { Deviation }\end{array}$} & \multirow{2}{*}{$\begin{array}{l}\text { Std. Error } \\
\text { Mean }\end{array}$} & \multicolumn{2}{|c|}{$\begin{array}{l}\text { 95\% Confidence Interval of } \\
\text { the Difference }\end{array}$} & \multirow[b]{2}{*}{$\mathrm{t}$} & \multirow[b]{2}{*}{$d f$} & \multirow{2}{*}{$\begin{array}{l}\text { Sig. (2- } \\
\text { tailed) }\end{array}$} \\
\hline & & & & Lower & Upper & & & \\
\hline KMS1 - KMS2 & 0.069 & 0.778 & 0.047 & -0.023 & 0.161 & 1.473 & 274 & .142 \\
\hline KMS1 - KMS3 & -0.033 & 0.825 & 0.050 & -0.131 & 0.065 & -.657 & 274 & .511 \\
\hline KMS1 - KMS4 & 0.062 & 0.854 & 0.052 & -0.040 & 0.163 & 1.200 & 274 & .231 \\
\hline KMS1 - KMS5 & $0.182^{* * *}$ & 0.914 & 0.055 & 0.073 & 0.290 & 3.299 & 274 & .001 \\
\hline KMS1 - KMS6 & $0.153^{* * *}$ & 1.017 & 0.061 & 0.032 & 0.274 & 2.490 & 274 & .013 \\
\hline KMS2 - KMS3 & -0.102 & 0.902 & 0.054 & -0.209 & 0.005 & -1.871 & 274 & .062 \\
\hline KMS2 - KMS4 & -0.007 & 0.888 & 0.054 & -0.113 & 0.098 & -.136 & 274 & .892 \\
\hline KMS2 - KMS5 & 0.113 & 0.992 & 0.060 & -0.005 & 0.230 & 1.885 & 274 & .061 \\
\hline KMS2 - KMS6 & 0.084 & 0.950 & 0.057 & -0.029 & 0.196 & 1.461 & 274 & .145 \\
\hline KMS3 - KMS4 & $0.095 * * *$ & 0.688 & 0.041 & 0.013 & 0.176 & 2.280 & 274 & .023 \\
\hline KMS3 - KMS5 & $0.215^{* * *}$ & 0.925 & 0.056 & 0.105 & 0.324 & 3.847 & 274 & .000 \\
\hline KMS3 - KMS6 & $0.185^{* * *}$ & 0.954 & 0.058 & 0.072 & 0.299 & 3.223 & 274 & .001 \\
\hline KMS4 - KMS5 & $0.120 * * *$ & 0.953 & 0.057 & 0.007 & 0.233 & 2.087 & 274 & .038 \\
\hline KMS4 - KMS6 & 0.091 & 0.949 & 0.057 & -0.022 & 0.204 & 1.589 & 274 & .113 \\
\hline KMS5 - KMS6 & -0.029 & 0.778 & 0.047 & -0.121 & 0.063 & -.620 & 274 & .536 \\
\hline
\end{tabular}

Table 7. Ranking of perceptions of the roles of specific KM processes in facilitating SSC strategy 


\begin{tabular}{cl}
\hline Rank & \multicolumn{1}{c}{ Perceptions of respondents } \\
\hline 1 & KMS3 Knowledge Diffusion - SSC Strategy \\
\hline 2 & KMS1 Knowledge Identification - SSC Strategy \\
\hline 3 & KMS4 Knowledge Integration - SSC Strategy \\
\hline 4 & KMS2 Knowledge Creation - SSC Strategy \\
\hline 5 & KMS6 Knowledge Application - SSC Strategy \\
\hline 6 & KMS5 Knowledge Modification - SSC Strategy \\
\hline Note: Following mean differences, KMS1 - KMS5, KMS1 - KMS6, KMS3 - KMS4, KMS3 - KMS5, KMS3 - \\
KMS6, and KMS4 - KMS5 are significant. Ranking is based on signs of mean differences.
\end{tabular}

First, we found that practitioners tend to agree that knowledge diffusion is the most important enabler of SSC strategy. Hence, the exchange, distribution, and sharing of knowledge within the focal firm and/or with external organizations can be confirmed as a very important function of KM.

Identification of new knowledge from internal and external sources was found to be the second most important enabler of SSC strategy. Third, internal knowledge integration and internal knowledge creation by firms are important, but perceived as relatively less important by practitioners for the development of SSC strategy. Modifying the existing knowledge base of the firm was viewed to be the least important of the specific KM processes in facilitating SSC strategy. Taking into account the first and the last finding above, indicates that practitioners generally believe that knowledge sharing and the identification of new knowledge beyond existing practices and boundaries of the firms are more important to the development of SSC than simply using the existing incumbent knowledge. Moreover, juxtaposition back to the responses to the open ended questions from the field experts substantiated the greater relative importance placed on knowledge transfer along the supply chain, for example with focal firms' supply chain partners, over other internal KM processes.

\subsection{The role of specific KM processes in facilitating SSC operations}

The findings in table 8 show that the survey respondents generally support the role of specific KM processes in facilitating SSC operations development. This is demonstrated by the high mean scores of responses and the significant correlations between the different KM processes.

Table 8. Roles of KM processes in facilitating SSC operations

\begin{tabular}{|c|c|c|c|c|c|c|c|c|c|}
\hline Pairs & Mean & $\begin{array}{l}\text { Std. } \\
\text { Dev. }\end{array}$ & $\begin{array}{l}\text { Std. Error } \\
\text { Mean }\end{array}$ & KMO1 & KMO2 & KMO3 & KMO4 & KMO5 & KMO6 \\
\hline $\begin{array}{l}\text { KMO1. Knowledge Identification - SSC } \\
\text { Operations }\end{array}$ & 5.309 & 1.277 & 0.077 & & & & & & \\
\hline $\begin{array}{l}\text { KMO2. Knowledge Creation - SSC } \\
\text { Operations }\end{array}$ & 5.371 & 1.285 & 0.077 & $.849 * *$ & 1 & & & & \\
\hline $\begin{array}{l}\text { KMO3. Knowledge Diffusion - SSC } \\
\text { Operations }\end{array}$ & 5.360 & 1.325 & 0.080 & $.738 * *$ & $.783^{* *}$ & 1 & & & \\
\hline $\begin{array}{l}\text { KMO4. Knowledge Integration - SSC } \\
\text { Operations }\end{array}$ & 5.349 & 1.308 & 0.079 & $.757^{* *}$ & $.826 * *$ & $.887 * *$ & 1 & & \\
\hline $\begin{array}{l}\text { KMO5. Knowledge Modification - SSC } \\
\text { Operations }\end{array}$ & 5.429 & 1.439 & 0.087 & $.802 * *$ & $.753^{* *}$ & $.753^{* *}$ & $.781^{* *}$ & 1 & \\
\hline $\begin{array}{l}\text { KMO6. Knowledge Application - SSC } \\
\text { Operations }\end{array}$ & 5.596 & 1.417 & 0.085 & $.741^{* *}$ & $.828 * *$ & $.760 * *$ & $.825^{* *}$ & $.858 * *$ & 1 \\
\hline
\end{tabular}


The paired-sample $t$ test was conducted to examine whether there are differences in perceptions in relation to different KM processes (see Table 9). Significant mean differences were identified, and accordingly the direction of the mean differences and the significant mean differences were used to identify the rankings of importance of the different KM processes in facilitating SSC operations (see Table 10). First, it can be observed that knowledge application was perceived to be the most important enabler of SSC operations. Hence, putting new knowledge into action by applying it to the routines of the firm is considered to be the most important KM process at the operational level.

Second, knowledge modification was also viewed as being considerably important to SSC operations. Thus, firms' ability to manipulate and alter the existing knowledge base is perceived by practitioners to be an important capability for SSC operations development. Third, compared with these two KM processes, knowledge creation, knowledge diffusion, knowledge integration and knowledge identification are less important to SSC operations development. These findings indicate that practitioners believe that to enable SSC development at the operational level, firms should focus on applying new knowledge and the alteration/adaptation of existing knowledge to the ongoing business practice.

Table 9. Paired perception mean differences on the role of specific KM processes in facilitating SSC operations

\begin{tabular}{|c|c|c|c|c|c|c|c|c|}
\hline \multirow[b]{2}{*}{ Pairs } & \multirow[b]{2}{*}{ Mean } & \multirow{2}{*}{$\begin{array}{c}\text { Std. } \\
\text { Deviation }\end{array}$} & \multirow{2}{*}{$\begin{array}{l}\text { Std. Error } \\
\text { Mean }\end{array}$} & \multicolumn{2}{|c|}{$\begin{array}{l}\text { 95\% Confidence } \\
\text { Interval of the } \\
\text { Difference }\end{array}$} & \multirow[b]{2}{*}{$\mathrm{t}$} & \multirow[b]{2}{*}{ df } & \multirow{2}{*}{$\begin{array}{l}\text { Sig. (2- } \\
\text { tailed) }\end{array}$} \\
\hline & & & & Lower & Upper & & & \\
\hline KMO1-KMO2 & -0.062 & 0.704 & 0.042 & -0.145 & 0.022 & -1.455 & 274 & .147 \\
\hline KMO1-KMO3 & -0.051 & 0.942 & 0.057 & -0.163 & 0.061 & -.896 & 274 & .371 \\
\hline KMO1-KMO4 & -0.040 & 0.901 & 0.054 & -0.147 & 0.067 & -.736 & 274 & .462 \\
\hline KM01-KMO5 & $-0.120 * * *$ & 0.869 & 0.052 & -0.223 & -0.017 & -2.289 & 274 & .023 \\
\hline KM01-KMO6 & $-0.287 * * *$ & 0.978 & 0.059 & -0.403 & -0.171 & -4.869 & 274 & .000 \\
\hline KMO2-KMO3 & 0.011 & 0.861 & 0.052 & -0.091 & 0.113 & .210 & 274 & .834 \\
\hline KMO2-KMO4 & 0.022 & 0.764 & 0.046 & -0.069 & 0.112 & .474 & 274 & .636 \\
\hline KMO2-KMO5 & -0.058 & 0.969 & 0.058 & -0.173 & 0.057 & -.996 & 274 & .320 \\
\hline KMO2-KMO6 & $-0.225^{* * *}$ & 0.802 & 0.048 & -0.321 & -0.130 & -4.665 & 274 & .000 \\
\hline KMO3-KMO4 & 0.011 & 0.625 & 0.038 & -0.063 & 0.085 & .290 & 274 & .772 \\
\hline KMO3-КMO5 & -0.069 & 0.977 & 0.059 & -0.185 & 0.047 & -1.172 & 274 & .242 \\
\hline KMO3-KMO6 & $-0.236 * * *$ & 0.955 & 0.058 & -0.350 & -0.123 & -4.106 & 274 & .000 \\
\hline KMO4-KMO5 & -0.080 & 0.917 & 0.055 & -0.189 & 0.029 & -1.447 & 274 & .149 \\
\hline KMO4-KMO6 & $-0.247 * * *$ & 0.813 & 0.049 & -0.344 & -0.151 & -5.043 & 274 & .000 \\
\hline KMO5-KMO6 & $-0.167^{* * *}$ & 0.760 & 0.046 & -0.258 & -0.077 & -3.649 & 274 & .000 \\
\hline
\end{tabular}

Table 10. Ranking of perceptions of the role of KM processes in facilitating SSC operations

\begin{tabular}{cl}
\hline Rank & \multicolumn{1}{c}{ Perceptions of respondents } \\
\hline 1 & KMO6 Knowledge Application - SSC Operations \\
\hline 2 & KMO5 Knowledge Modification - SSC Operations \\
\hline 3 & KMO2 Knowledge Creation - SSC Operations \\
\hline 4 & KMO3 Knowledge Diffusion - SSC Operations \\
\hline 5 & KMO4 Knowledge Integration - SSC Operations \\
\hline 6 & KMO1 Knowledge Identification - SSC Operations \\
\hline
\end{tabular}


Note: Following mean differences, KMO1 - KMO5, KMO1 - KMO6, KMO2 - KMO6, KMO3 - KMO6, KMO4

$-\mathrm{KMO}$, and $\mathrm{KMO} 5-\mathrm{KMO} 6$ are significant. Ranking is based on signs of mean differences.

\subsection{Comparing the role of KM processes in facilitating SSC strategy and SSC operations}

To compare whether the respondents perceived the KM processes as having the same or a different level of impact on SSC strategy and SSC operations development, a paired-sample $t$ test was again conducted (see Table 11). The result shows that knowledge identification is perceived as more important to the strategic development of SSC than to SSC operations. Similarly, knowledge diffusion was found to be more important at the strategic level than at the operational level of SSCs. Both of these results imply that learning beyond existing knowledge bases through activities such as boundary spanning and knowledge exchange is more important at the strategic level than at the operational level. Knowledge modification and knowledge application were found to be more important to SSC operations development than to SSC strategic development. Knowledge creation and knowledge integration on the other hand, appeared to hold similar importance to strategic and operations SSC development. These findings indicate an important implication for practising managers. Notably, that different KM processes may have different uses and influence at either the strategic or operational level. At the strategic level, our findings suggest that practitioners tend to believe that more 'radical' new knowledge (from internal or external sources) is needed for augmenting SSCM. On the other hand, at the operational level, adaptation of existing knowledge to ongoing business practice and applying new knowledge to the business/operations processes are more important to overall SSC development.

Table 11. Paired perception mean differences on the role of KM processes in facilitating SSC strategies versus SSC operations

\begin{tabular}{|c|c|c|c|c|c|c|c|c|}
\hline \multirow[b]{2}{*}{ Pairs } & \multirow[b]{2}{*}{ Mean } & \multirow{2}{*}{$\begin{array}{c}\text { Std. } \\
\text { Deviation }\end{array}$} & \multirow{2}{*}{$\begin{array}{l}\text { Std. } \\
\text { Error } \\
\text { Mean }\end{array}$} & \multicolumn{2}{|c|}{$\begin{array}{l}\text { 95\% Confidence } \\
\text { Interval of the } \\
\text { Difference }\end{array}$} & \multirow[b]{2}{*}{$\mathrm{T}$} & \multirow[b]{2}{*}{ df } & \multirow{2}{*}{$\begin{array}{l}\text { Sig. (2- } \\
\text { tailed) }\end{array}$} \\
\hline & & & & Lower & Upper & & & \\
\hline KMS1 - KMO1 & $0.182^{* * *}$ & 0.890 & 0.054 & 0.076 & 0.287 & 3.389 & 274 & .001 \\
\hline KMS2 - KMO2 & 0.051 & 0.857 & 0.052 & -0.051 & 0.153 & .985 & 274 & .326 \\
\hline KMS3 - KMO3 & $0.164^{* * *}$ & 0.999 & 0.060 & 0.045 & 0.282 & 2.715 & 274 & .007 \\
\hline KMS4 - KMO4 & 0.080 & 0.975 & 0.059 & -0.036 & 0.196 & 1.361 & 274 & .175 \\
\hline KMS5 - KMO5 & $-0.120 * * *$ & 0.961 & 0.058 & -0.234 & -0.006 & -2.071 & 274 & .039 \\
\hline KMS6 - KMO6 & $-0.258 * * *$ & 0.921 & 0.056 & -0.368 & -0.149 & -4.646 & 274 & .000 \\
\hline
\end{tabular}

\section{Discussion and conclusions}

We used the NRBV and the KBV theoretical lenses in conjunction with the extant literature to derive a set of propositions linking KM capability with SSCs. Sustainability, as was noted, is one of the least examined NRBV strategies, and as such we contribute to the NRBV by identifying an endogenous sustainability capability. We broaden the remit of these theoretical lenses by showing that KM capability plays a catalytic role in driving forward SSC and the TBL. We tested the veracity of the 
propositions by examining whether or not they are supported by practicing mangers' perceptions. We found significant support for our propositions. Equally importantly, our results suggest that practitioners do not ascribe equal utility to KM processes so they are not all of equal importance. Moreover, our analysis shows that while practitioners perceived KM processes to be of benefit to both the strategic development and operational development of SSCs, they were also of the view that different KM processes had dissimilar levels of impact on SSC strategies or operations. Overall, practitioners tended to highlight the importance of more radical changes or innovations by firms in order to enable SSCs. This finding supports the stance, rooted in the KBV, that more diversified knowledge resources are available within the inter-firm network, such as the supply chain, as opposed to within the firm's own boundaries (Kogut, 2000). Our findings also support the view, as noted by Dyer and Nobeoka (2000), that (provided that strong identity and coordinating rules are present) a supply chain can be superior to a firm at creating and recombining knowledge because of the greater diversity of knowledge accessible. As a particular type of organisational network, our findings therefore imply that supply chains can be an important source of knowledge creation and development to facilitate supply chain sustainability.

Our analysis suggests that practitioners are not unequivocally convinced of the feasibility of TBL in relation to supply chains. This is a significant finding with major implications for the take up of TBL and SSC by firms. We base our conclusion on the importance attributed to managerial cognition and framing and their effect on firms' abilities to profitably enact environmentally proactive strategies, discussed previously (Hart and Dowell, 2011; King and Lenox, 2002; Tenbrunsel et al., 2000). Our finding also suggests a gap between the stance adopted by the captains of industry (for example, see Carolyn Fairbairn's comment presented previously) and perception of senior practitioners in our study. Such a gap may not bode well for widespread application of TBL at least where supply chains are concerned.

Based on our analysis, some guidelines for future research on KM-enabled SSCM can be advanced. Firstly, although there is general consensus from our respondents with regards to the importance of supply chain sustainability development and the importance of KM in facilitating that development, further research is needed to substantiate the feasibility and benefits of TBL goals in the supply chain. Moreover, greater effort from policy makers is required to heighten practitioners' awareness of the competitive benefits of implementing SSCS and TBL. Second, the positive role of KM in supply chain sustainable development is, in part, indirect. Thus, effective KM can help firms to develop better innovations in SSC strategies and operations, but may or may not generate immediate performance improvement. In order to build stronger chains of evidence that can persuade practitioners of the importance of investing in KM to facilitate supply chain sustainability, further research is therefore needed to more clearly distinguish the potential direct from the potential indirect effects of KM. Third, the effective management of external knowledge appeared to be equally important as the effective management of internal knowledge for developing SSCs. This indicates that more intensive research on the specific knowledge transfer practices, mechanisms, routines and tools and techniques that most effectively facilitate the knowledge transfer processes should be a priority. This would be a fertile area for in-depth case study based approaches. Fourth, given that our study is mainly exploratory in nature, the sample respondents were drawn from two large practitioner databases on a purposeful sampling basis. Despite the current sample being relevant to the context 
of this study, future research may broaden the sample base and seek to validate the propositions using larger industrial sampling frames and explanatory research designs.

\subsection{Practical and managerial implications}

Our empirical enquiry has established that there are differences in the locus of the six different KM processes' contribution to SSC development, and which KM processes are primarily a strategic responsibility, and which are primarily an operations-level responsibility.

Knowledge identification, knowledge diffusion and knowledge integration need to be addressed by firms primarily through a 'strategic lens'. As such, the identification, diffusion and integration processes in KM should be viewed as the responsibility of senior managers within the supply chain firms. Hence senior managers should take the responsibility for leading the identification of new techniques, technologies and information; and for accessing external sources of knowledge and for taking the lead to initiate boundary-spanning activities. Likewise, senior managers also have the greater responsibility - through boundary spanning activities or by putting in place the appropriate internal communication channels - for leading the effective exchange, distribution and sharing of knowledge within the firm and with other members of the chain. Perhaps not surprisingly given the potential complexity of integrating new knowledge with existing knowledge, our findings also indicate that knowledge integration processes should be led primarily as a strategic activity by senior managers.

Knowledge application, knowledge modification and knowledge creation on the other hand primarily need to be addressed by those who are more directly engaged with the detailed design, coordination and management of the value adding processes. Transforming new knowledge into action and applying knowledge to the existing routines of the firm should primarily be led by operations-based/front-line employees, as should the process of tailoring, altering (and hence updating) the existing knowledge base. This is intuitively logical in both cases, given operations-based employees' closer proximity to, and greater familiarity with the detailed workings of the production/service delivery processes and their interfaces with those of adjacent supply chain members.

The finding that the knowledge creation process element has a higher ranked role at the operational level than at the strategic level in facilitating SSCs supports the notion that the development of new ideas and innovation should primarily be a bottom-up activity. This in turn implies that employees working in operations-based/front-line roles must be afforded the support, time and resources to enable new idea generation activities to flourish.

Our findings can also help managers to better plan and direct resource investments in KM processes to where they would appear to be most beneficial. For example, whilst at an introductory level, education and training in KM would be likely to cover all KM processes for all employees, our results provide guidance regarding who in the firm should receive more in-depth training on specific individual KM processes for maximum overall benefit. This is important because resources available to the firm to devote to specific training are often sparse and hence need to be used as 
advantageously as possible. Our findings indicate that resources (e.g. intelligence gathering tools, database or communication systems or bespoke training) supporting knowledge identification, diffusion or integration processes should preferentially be channelled to the strategic level, while those resources supporting knowledge application, modification and creation processes might be better prioritised towards the operations areas.

Our findings also have important implications for policy at different levels. At the national level enhancing sustainability is important because of government's environmental commitments and competiveness agendas (e.g. UK PIc). Yet, the practicing managers' scepticism as to the feasibility of TBL and SSC, as was pointed out, is likely to limit adoption by a large number of firms and supply chains. Employers' organisation such as the Confederation of British Industry and professional organisations such as the Chartered Management Institute may offer lower institutional force but are equally committed to "purpose", which in turn encompasses TBL and SSC. Hence, it is important that government and organisations such as the $\mathrm{CBI}$ and $\mathrm{CMI}$ promote TBL and SSC by identifying exemplar firms, providing case studies demonstrating the contribution of SSC/TBL to firm's competiveness, including sustainability as part of the industrial strategy, and creating awareness.

Our findings have another important implication for the design of future research at the KM-TBLSSC nexus. By identifying which KM processes most contribute to SSC strategy development and which contribute most to SSC operations development, and therefore by identifying with whom the primary responsibility for each of the six KM processes resides, this study provides guidance to future researchers on whom within organisations is likely to be the most valuable informant/participant for future research seeking to develop a deeper understanding of each specific KM process. Our findings infer that senior managers should be approached for more in depth research on knowledge identification, diffusion and integration; while operations-based/front-line employees should be approached for more in depth studies into knowledge creation, application and modification processes.

This paper is an early attempt to explicitly explore the possible benefits that KM can bring to firms' development of SSC. The paper substantiates the positive relationship between SSCM and firms' development of sustainable competitive advantages. The paper offers both researchers and managers a new angle through which to view and consider the transformation towards SSCM, and in doing so offers impetus for future research.

\section{Acknowledgements}

(To be added.)

\section{References}

Alavi, M. and Leidner, D. 2001. "Knowledge management and knowledge management systems: Conceptual foundations and research issues", MIS Quarterly, Vol.25, No.1, pp. 107-136. 
Aragon-Correa, J. A. and Sharma, S. 2003. "A contingent resource-based view of proactive corporate environmental strategy", Academy of Management Review, Vol.28, pp. 71-88.

Barney, J. B. 2001. "Resource-based theories of competitive advantage: A ten-year retrospective on the resource- based view", Journal of Management, Vol.27, pp. 643-650.

Beske, P., Koplin, J. and Seuring, S. 2008 "The use of environmental and social standards by German first-tier suppliers of the Volkswagen AG." Corporate Social Responsibility \& Environmental Management, Vol.15, No.2, pp. 63-75.

Bessant, J., Kaplinsky, R. and Lamming, R. C. 2003. "Putting supply chain learning into practice", International Journal of Operations \& Production Management, Vol.23, No.2, pp. 167-184.

Blome, C., Schoenherr, T. and Eckstein, D. 2014. "The impact of knowledge transfer and complexity on supply chain flexibility: A knowledge-based view", International Journal of Production Economics, Vol.147, Part B, pp. 307-316.

Boerner, C. S., Macher, J. T. and Teece, D. J. 2003. "A Review and Assessment of Organizational Learning in Economic Theories", In Handbook of Organizational Learning and Knowledge, (Eds, Dierkes, M., Antal, A. B., Child, J. and Nonaka, I.) Oxford University Press, Oxford, pp. 89-117.

Bouncken, R. B., Pluschke, B. D., Pesch, R. and Kraus, S. 2016. "Entrepreneurial orientation in vertical alliances: joint product innovation and learning from allies", Review of Managerial Science, Vol.10, No.2, pp. 381-409.

Bryman, A. and Cramer, D. 2001. Quantitative Data Analysis with SPSS Release 10 for Windows, Routledge, Hove.

Carter, C. R. and Jennings, M. M. 2002. "Social responsibility and supply chain relationships", Transportation Research Part E: Logistics and Transportation Review, Vol.38, No.1, pp. 37-52.

Carter, C. R. and Rogers, D. S. 2008. "A framework of sustainable supply chain management: moving toward new theory." International Journal of Physical Distribution \& Logistics Management, Vol.38, No.5, pp. 360-387.

Chaabane, A., Ramudhin, A. and Paquet, M. 2011. "Designing supply chains with sustainability considerations", Production Planning \& Control, Vol.22, No.8, pp. 727-741.

Cheng, J.-H., Yeh, C.-H. and Tu, C.-W. 2008. "Trust and knowledge sharing in green supply chains", Supply Chain Management: An International Journal, Vol.13, No.4, pp. 283-295.

Christmann, P. 2000. "Effects of 'best practices' of environmental management on cost advantage: the role of complementary assets", Academy of Management Journal, Vol.43, No.4, pp. 663-680.

Confino J. 2014. "Society must call business' bluff on its fixation with profit maximisation", The Guardian: 4 November, URL: https://www.theguardian.com/sustainablebusiness/2014/nov/05/society-business-fixation-profit-maximisation-fiduciary-duty

Cohen, W. M. and Levinthal, D. A. 1990. "Absorptive capacity: A new perspective on learning and innovation", Administrative Science Quarterly, Vol.35, pp. 128-152.

Conner, K. R. and Prahalad, C. K. 1996. "A resource-based theory of the firm: Knowledge versus Opportunism", Organization Science, Vol.7, No.5, pp. 477-501.

Davenport, T. H., De Long, D. W. and Beers, M. C. 1998. "Successful knowledge management projects", Sloan Management Review, Vol. Winter, pp. 43-57.

du Plessis, M. 2007. "The role of knowledge management in innovation", Journal of Knowledge Management, Vol.11, No.4, pp. 20-29.

Dyer, J. H. and Nobeoka, K. 2000. "Creating and managing a high-performance knowledge-sharing network: The Toyota case", Strategic Management Journal, Vol.21, No.3, pp. 345-367. 
Easterby-Smith, M. and Lyles, M. 2003. "Re-reading Organizational Learning: Selective memory, forgetting, and adaptation.", Academy of Management Executive, Vol.17, No.2, pp. 51-55.

Easterby-Smith, M. and Prieto, I. M. 2008. "Dynamic Capabilities and Knowledge Management: an Integrative Role for Learning?", British Journal of Management, Vol.19, No.3, pp. 235-249.

Elkington, J. 1998. Cannibals with Forks: The Triple Bottom Line of the 21st Century, New Society Publishers, Stoney Creek, CT.

Flint, D. J. and Golicic, S. L. 2009. "Searching for competitive advantage through sustainability: A qualitative study in the New Zealand wine industry", International Journal of Physical Distribution \& Logistics Management, Vol.39, No.10, pp. 841-860.

Ford.com 2010. Ford Motor Companies.

FT. 2017. "Business must help fix the failures of capitalism", Financial Times, 23 October, URL: https://www.ft.com/content/da9aa4ce-b7e4-11e7-8c12-5661783e5589.

Gallear, D., Ghobadian, A. and Chen, W. 2012. "Corporate responsibility, supply chain partnership and performance: An empirical examination", International Journal of Production Economics, Vol.140, No.1, pp. 83-9.

Gilmore, D. 2015. "Any limits to large companies' supply chain control?", Supply Chain Digest, URL: http://www.scdigest.com/assets/firstthoughts/15-03-12.php?cid=9092.

Gopal, P. R. C. and Thakkar, J. 2016. "Sustainable supply chain practices: an empirical investigation on Indian automobile industry", Production Planning \& Control, Vol.27, No.1, pp. 49-64.

Govindan, K., Khodaverdi, R., \& Jafarian, A. 2013. "A fuzzy multi criteria approach for measuring sustainability performance of a supplier based on triple bottom line approach", Journal of Cleaner Production, Vol.47, pp. 345-354.

Grant, R. M. 1996. "Toward a knowledge-based theory of the firm", Strategic Management Journal, Vol.17, Winter special issue, pp. 109-122.

Grant, R. M. and Baden-Fuller, C. 1995. "A knowledge-based theory of inter-firm collaboration", Academy of Management Best Paper Proceedings, Vol.55, pp. 17-21.

Hall, J. and Matos, S. 2010. "Incorporating impoverished communities in sustainable supply chains", International Journal of Physical Distribution \& Logistics Management, Vol.40, No.1, pp. 124-147.

Handfield, R. B., Ragatz, G. L., Petersen, K. J. and Monczka, R. M. 1999. "Involving suppliers in new product development", California Management Review, Vol.42, No.1, pp. 59-82.

Hart, S. L. 1995. "A natural-resource-based view of the firm", Academy of Management Review, Vol.20, No.4, pp. 986-1014.

Hart, S. L. 2007. Capitalism at the crossroads: Aligning business, earth, and humanity, Wharton School Publishing, Upper Saddle River, NJ.

Hart, S. L. and Dowell, G. 2011. "A natural resource-based view of the firm: Fifteen years after", Journal of Management, Vol.37, pp. 1464-1479.

Hart S. L. and Sharma S. 2004. "Engaging fringe stakeholders for competitive imagination", Academy of Management Executive, Vol.18, No.1, pp. 7-18.

He, Q., Ghobadian, A., Gallear, D. and Sohal, A. 2006. "Knowledge transfer between supply chain partners: a conceptual model", International Journal of Process Management and Benchmarking, Vol.1, No.3, pp. 231-262.

He, Q., Ghobadian, A. and Gallear, D. 2013. "Knowledge Acquisition in Supply Chain Partnerships: The Role of Power", International Journal of Production Economics, Vol.141, No.2, pp. 605-618. 
Hollos, D., Blome, C. and Foerstl, K. 2012. "Does sustainable supplier co-operation affect performance? Examining implications for the triple bottom line", International Journal of Production Research, Vol.50, No.11, pp. 2968-2986.

Hult, G. T. M., Ketchen, D. J. and Slater, S. F. 2004. "Information processing, knowledge development, and strategic supply chain performance", Academy of Management Journal, Vol.47, No.2, pp. 241253.

Hult, G. T. M., Ketchen, D. J., David J., Cavusgil, S. T. and Calantone, R. J. 2006. "Knowledge as a strategic resource in supply chains", Journal of Operations Management, Vol.24, No.5, pp. 458475.

Hult, G. T. M., Ketchen, D. J., Arrfelt, M. 2007. "Strategic supply chain management: Improving performance through a culture of competitiveness and knowledge development". Strategic Management Journal, Vol.28, No.10, pp. 1035-1052.

Isaksson, R., Johansson, P. and Fischer, K. 2010. "Detecting supply chain innovation potential for sustainable development", Journal of Business Ethics, Vol.97, pp. 425-442.

Irani, Z., Kamal, M. M., Sharif, A. and Love, P. E. D. 2017. "Enabling sustainable energy futures: factors influencing green supply chain collaboration", Production Planning \& Control, Vol.28, No.6-8, pp. 684-705.

Johnsen, T., Phillips, W., Caldwell, N. and Lewis, M. 2006. "Centrality of customer and supplier interaction in innovation", Journal of Business Research, Vol.59, No.6, pp. 671-678.

Judge, W. Q. and Douglas, T. J. 1998. "Performance implications of incorporating natural environmental issues into the strategic planning process: An empirical assessment", Journal of Management Studies, Vol.35, No.2, pp. 241-262.

Karim, S. and Mitchell, W. 2000. "Path-dependent and path-breaking change: reconfiguring business resources following acquisitions in the U.S. medical sector, 1978-1995", Strategic Management Journal, Vol.21, No.10-11, pp. 1061-1081.

King, A. and Lenox, M. 2002. "Exploring the locus of profitable pollution reduction", Management Science, Vol.48, pp. 289-299.

Kogut, B. 2000. "The network as knowledge: Generative rules and the emergence of structure", Strategic Management Journal, Vol.21, No.3, pp. 405-425.

Kotabe, M., Martin, X. and Domoto, H. 2003. "Gaining from vertical partnerships: Knowledge transfer, relationship duration, and supplier performance improvement in the U.S. and Japanese automotive industries", Strategic Management Journal, Vol.24, No.4, pp. 293-316.

Lawson, B., Petersen, K., Cousins, P. D. and Handfield, R. B. 2009. "Knowledge Sharing in Interorganizational Product Development Teams: The Effect of Formal and Informal Socialization Mechanisms", Journal of Product Innovation Management, Vol.26, No.2, pp. 156-172.

Lee, V.-H., Ooi, K.-B., Chong, A. Y.-L. and Lin, B. 2015. "A structural analysis of greening the supplier, environmental performance and competitive advantage", Production Planning \& Control, Vol.26, No.2, pp. 116-130.

Linton, J. D., Klassen, R. and Jayaraman, V. 2007. "Sustainable supply chains: An introduction", Journal of Operations Management, Vol.25, No.6, pp. 1075-1082.

Lorenzoni, G. and Lipparini, A. 1999. "The leveraging of interfirm relationships as a distinctive organizational capability: A longitudinal study", Journal of Strategic Management, Vol.20, pp. 317338. 
Luthra, S., Garg, D. and Haleem, A. 2015. "Critical success factors of green supply chain management for achieving sustainability in Indian automobile industry", Production Planning \& Control, Vol.26, No.5, pp. 339-362.

Malhotra, A., Gosain, S. and El Sawy, O. A. 2005. "Absorptive capacity configurations in supply chains: Gearing for partner-enabled market knowledge creation", MIS Quarterly, Vol.29, No.1, pp. 145187.

Markley, M. J. and Davis, L. 2007. "Exploring future competitive advantage through sustainable supply chains." International Journal of Physical Distribution \& Logistics Management, Vol.37, No.9, pp. 763-774.

Meier, M. 2011. "Knowledge management in strategic alliances: A review of empirical evidence", International Journal of Management Reviews, Vol.13, pp. 1-23.

Modi, S. B. and Mabert, V. A. 2007. "Supplier development: Improving supplier performance through knowledge transfer", Journal of Operations Management, Vol.25, pp. 42-64.

Mollenkopf, D., Stolze, H., Tate, W. L. and Ueltschy, M. 2010. "Green, lean, and global supply chains", International Journal of Physical Distribution \& Logistics Management, Vol.40, No.1, pp. 14-41.

Musarra, G., Robson, M. J. and Katsikeas, C. S. 2016. "The influence of desire for control on monitoring decisions and performance outcomes in strategic alliances", Industrial Marketing Management, Vol.55, pp. 10-21.

Pagell, M. and Wu, Z. 2009. "Building a more complete theory of sustainable supply chain management using case studies of 10 exemplars", Journal of Supply Chain Management: A Global Review of Purchasing \& Supply, Vol.45, No.2, pp. 37-56.

Palazzo, G. and Scherer, A. 2008. "Corporate Social Responsibility, Democracy, and the Politicization of the Corporation", Academy of Management Review, Vol.33, No.3, pp. 773-775.

Pawlowsky, P., Forslin, J. and Reinhardt, R. 2003. In Handbook of Organizational Learning and Knowledge(Eds, Dierkes, M., Antal, A. B., Child, J. and Nonaka, I.) Oxford University Press, New York, pp. 775-793.

Porter, M. E. and Kramer, M. R. 2002. "The Competitive Advantage of Corporate Philanthropy", Harvard Business Review, Vol.80, No.12, pp. 56-69.

Sarkis, J. 2001. "Manufacturing's role in corporate environmental sustainability", International Journal of Operations \& Production Management, Vol.21, No.5/6, pp. 666-686.

Seuring, S. and Muller, M. 2008. "From a literature review to a conceptual framework for sustainable supply chain management." Journal of Cleaner Production, Vol.16, No.15, pp. 1699-1710.

Shrivastava, P. 1995. "Environmental technologies and competitive advantage", Strategic Management Journal, Vol.16, pp. 183-200.

Spence, L. and Bourlakis, M. 2009. "The evolution from corporate social responsibility to supply chain responsibility: the case of Waitrose", Supply Chain Management: An International Journal, Vol.14, No.4, pp. 291-302.

Stokes, S. and Tohamy, N. 2009. "7 Traits of a Green Supply Chain", Supply Chain Management Review, Vol.13, No.7, pp. 8-9.

Tate, W. L., Ellram, L. M. and Kirchoff, J. F. 2010. "Corporate social responsibility reports: A thematic analysis related to supply chain management", Journal of Supply Chain Management: A Global Review of Purchasing \& Supply, Vol.46, No.1, pp. 19-44.

Tenbrunsel, A. E., Wade-Benzoni, K. A., Messick, D. M. and Bazerman, M. H. 2000. "Understanding the influence of environmental standards on judgments and choices", Academy of Management Journal, Vol.43, pp. 854-866. 
Wadhwa, S. and Saxena, A. 2007. "Decision knowledge sharing: flexible supply chains in KM context", Production Planning \& Control, Vol.18, No.5, pp. 436-452.

Winter, S. G. 2000. "The Satisficing Principle in Capability Learning", Strategic Management Journal, Vol.21, No.10-11, pp. 981-996.

Wood, G., Dibben, P. and Meira, J. 2016. "Knowledge transfer within strategic partnerships: the case of HRM in the Brazilian motor industry supply chain", International Journal of Human Resource Management, Vol.27, No.20, pp. 2398-2414.

Zhu, Q. and Sarkis, J. 2004. "Relationships between operational practices and performance among early adopters of green supply chain management practices in Chinese manufacturing enterprises", Journal of Operations Management, Vol.22, No.3, pp. 265-289.

Zhu, T., Ku, T. and Xu, L. 2009. "Knowledge Sharing in Green Supply Chain Based on Trust Adjustment Mechanism", MASS '09. International Conference on Management and Service Science, Wuhan, China, pp. 1-4.

Zhu, Q., Sarkis, J. and Lai, K-h. 2012. "Green supply chain management innovation diffusion and its relationship to organizational improvement: An ecological modernization perspective", Journal of Engineering and Technology Management, Vol.29, pp. 168-185. 


\begin{tabular}{|c|c|c|c|}
\hline Items Number & Items & Source & Scale \\
\hline & $\begin{array}{l}\text { To what extent do you agree or disagree with the } \\
\text { following statements? }\end{array}$ & & $\begin{array}{l}7 \text { = strongly agree; } \\
1 \text { = strongly } \\
\text { disagree. }\end{array}$ \\
\hline GKM1 & $\begin{array}{l}\text { Firms will realise the economic gain from adopting more } \\
\text { proactive social and environmental strategies. }\end{array}$ & (Tate et al., 2010) & \\
\hline GKM2 & $\begin{array}{l}\text { Adopting supply chain strategies that simultaneously } \\
\text { emphasise economic, environmental and social } \\
\text { performance goals will contribute to the competitive } \\
\text { advantages of firms. }\end{array}$ & $\begin{array}{l}\text { (Markley and Davis, } \\
\text { 2007) }\end{array}$ & \\
\hline GKM3 & $\begin{array}{l}\text { To meet economic, environmental and social performance } \\
\text { goals simultaneously, firms need } \\
\text { innovation/transformation of their existing practices. }\end{array}$ & $\begin{array}{l}\text { (Shrivastava, 1995; } \\
\text { Pagell and Wu, } \\
\text { 2009) }\end{array}$ & \\
\hline GKM4 & $\begin{array}{l}\text { Effective knowledge management is essential for a firm's } \\
\text { development of sustainable supply chain strategies. }\end{array}$ & $\begin{array}{l}\text { (Pagell and Wu, } \\
\text { 2009) }\end{array}$ & \\
\hline GKM5 & $\begin{array}{l}\text { Effective knowledge management by a firm is critical for } \\
\text { the innovation needed for more sustainable supply chain } \\
\text { operations. }\end{array}$ & $\begin{array}{l}\text { (Shrivastava, 1995; } \\
\text { Sarkis, 2001) }\end{array}$ & \\
\hline \multirow[t]{2}{*}{ GKM6 } & $\begin{array}{l}\text { Firms with effective knowledge management are more } \\
\text { able to develop sustainable supply chain management. }\end{array}$ & (Hart, 1995) & \\
\hline & $\begin{array}{l}\text { At the strategic level, how important is each of the } \\
\text { following knowledge management processes to a firm's } \\
\text { development of Sustainable Supply Chain Strategies? }\end{array}$ & & $\begin{array}{l}7 \text { = Very important; } \\
1 \text { = Not important } \\
\text { at all. }\end{array}$ \\
\hline KMS1 & $\begin{array}{l}\text { Identification of new techniques, technologies, } \\
\text { information, and knowledge from internal and external } \\
\text { sources. }\end{array}$ & $\begin{array}{l}\text { (Pawlowsky et al., } \\
\text { 2003) }\end{array}$ & \\
\hline KMS2 & $\begin{array}{l}\text { Creation of knowledge, development of new ideas and } \\
\text { innovation in organizations. }\end{array}$ & $\begin{array}{l}\text { (Pawlowsky et al., } \\
\text { 2003) }\end{array}$ & \\
\hline KMS3 & $\begin{array}{l}\text { Diffusion of knowledge through exchange, distribution, } \\
\text { and sharing of knowledge within the firm and/or with } \\
\text { external organizations in a supply chain. }\end{array}$ & $\begin{array}{l}\text { (Pawlowsky et al., } \\
\text { 2003) }\end{array}$ & \\
\hline KMS4 & $\begin{array}{l}\text { Integration of new knowledge into existing systems of the } \\
\text { firm in a supply chain at collective level, or individual level, } \\
\text { or both. }\end{array}$ & $\begin{array}{l}\text { (Pawlowsky et al., } \\
\text { 2003) }\end{array}$ & \\
\hline KMS5 & $\begin{array}{l}\text { Modifying, altering and renewing the existing knowledge } \\
\text { base of the firm in a supply chain. }\end{array}$ & $\begin{array}{l}\text { (Pawlowsky et al., } \\
\text { 2003) }\end{array}$ & \\
\hline \multirow[t]{2}{*}{ KMS6 } & $\begin{array}{l}\text { Transforming new knowledge into action, and applying } \\
\text { knowledge to routines of the firm in a supply chain. }\end{array}$ & $\begin{array}{l}\text { (Pawlowsky et al., } \\
\text { 2003) }\end{array}$ & \\
\hline & $\begin{array}{l}\text { At the operational level, how important is each of the } \\
\text { following knowledge management processes to a firm's } \\
\text { development of Sustainable Supply Chain Operations? }\end{array}$ & & $\begin{array}{l}7 \text { = Very important; } \\
1 \text { = Not important } \\
\text { at all. }\end{array}$ \\
\hline KMO1 & $\begin{array}{l}\text { Identification of new techniques, technologies, } \\
\text { information, and knowledge from internal and external } \\
\text { sources. }\end{array}$ & $\begin{array}{l}\text { (Pawlowsky et al., } \\
\text { 2003) }\end{array}$ & \\
\hline KMO2 & $\begin{array}{l}\text { Creation of knowledge, development of new ideas and } \\
\text { innovation in organizations. }\end{array}$ & $\begin{array}{l}\text { (Pawlowsky et al., } \\
\text { 2003) }\end{array}$ & \\
\hline KMO3 & $\begin{array}{l}\text { Diffusion of knowledge through exchange, distribution, } \\
\text { and sharing of knowledge within the firm and/or with } \\
\text { external organizations in a supply chain. }\end{array}$ & $\begin{array}{l}\text { (Pawlowsky et al., } \\
\text { 2003) }\end{array}$ & \\
\hline KMO4 & $\begin{array}{l}\text { Integration of new knowledge into existing systems of the } \\
\text { firm in a supply chain at collective level, or individual level, } \\
\text { or both. }\end{array}$ & $\begin{array}{l}\text { (Pawlowsky et al., } \\
\text { 2003) }\end{array}$ & \\
\hline KMO5 & $\begin{array}{l}\text { Modifying, altering and renewing the existing knowledge } \\
\text { base of the firm in a supply chain. }\end{array}$ & $\begin{array}{l}\text { (Pawlowsky et al., } \\
\text { 2003) }\end{array}$ & \\
\hline KMO6 & $\begin{array}{l}\text { Transforming new knowledge into action, and applying } \\
\text { knowledge to routines of the firm in a supply chain. }\end{array}$ & $\begin{array}{l}\text { (Pawlowsky et al., } \\
\text { 2003) }\end{array}$ & \\
\hline
\end{tabular}

